\title{
Reducing Numbers of Sex Partners: Do We Really Need Special Interventions for Sexual Concurrency?
}

\author{
Seth C. Kalichman • Tamar Grebler
}

Published online: 16 June 2010

(C) Springer Science+Business Media, LLC 2010

Multiple and overlapping sexual relationships, commonly referred to as sexual concurrency, are believed by some to account for the rapid spread of HIV infection in sub-Saharan Africa [1]. Research shows that concurrent sex partners are prevalent in several populations hit hardest by AIDS including gay communities, commercial sex workers, and some countries of sub-Saharan Africa. Recent research shows sexual concurrency may be playing a role in resurgent HIV infections among gay and bisexual men in North America [2] and emerging HIV epidemics among men who have sex with men in Asia [3]. In addition to epidemiological trends, the potential impact of concurrent sex partners on the spread of HIV transmission is biologically grounded. Sexual concurrency is thought to afford the rapid turnover of HIV when multiple partners are exposed to the virus during the brief and highly infectious period of acute infection [4]. Mathematical models suggest that concurrent sex partners during acute HIV infection may be a driving force in heterosexually transmitted HIV epidemics of southern Africa [5, 6]. Other known and unknown co-factors for HIV transmission also interact with sexual concurrency to propel HIV epidemics.

While stimulating great interest, the existing empirical research on the role of sexual concurrency in HIV epidemics is not definitive. In the February 2010 issue of AIDS and Behavior (volume 14, Number 1) Lurie and Rosenthal [7] pointed out that sexual concurrency has not yet been empirically shown to increase HIV transmission beyond what would be expected from multiple sex partnerships that do not overlap in time. They also note that

S. C. Kalichman $(\bowtie) \cdot$ T. Grebler

Department of Psychology, University of Connecticut, 406 Babbidge Road, Storrs, CT 06269, USA

e-mail: seth.k@uconn.edu epidemiological evidence is mixed as to whether sexual concurrency is spreading HIV in southern Africa and that there is even evidence that polygamy, certainly an example of concurrency, can protect against HIV transmission [7-10]. At the heart of the controversy surrounding the role of sexual concurrency in HIV epidemics is the question of whether limited HIV prevention resources should be directed at interventions to target sexual concurrency $[1,11]$. Furthermore, even if interventions are designed to specifically target sexual concurrency, it is not clear how they would differ from programs that aim to reduce notnecessarily concurrent multiple sex partners. Sending a strong message against concurrent partnerships may even have adverse outcomes if people believe they are safe by having serial multiple partners.

The jury may be out on whether sexual concurrency is necessary for the rapid spread of HIV, but there is no disputing that multiple sex partners, whether concurrent or serial, are important in HIV epidemics. Recognizing the need for behavioral interventions that reduce numbers of sex partners regardless of their temporal sequencing is not new. Throughout the 1980s and 1990s social marketing campaigns for HIV prevention in US gay communities commonly promoted reducing numbers of sex partners. Indeed, many of the early HIV prevention successes in gay communities and countries like Uganda are attributed to aggressive efforts aimed at reducing numbers of sex partners [12, 13]. Mass public health message campaigns result in behavior change for only a segment of a population. Thus, more focused behavioral interventions are needed to reduce high-risk behaviors, including reducing numbers of sex partners, in populations with high HIV prevalence.

Several controlled intervention trials have demonstrated significant reductions in numbers of sex partners. Table 1 summarizes the findings from 15 selected prevention trials 
Table 1 Partner reduction outcomes from selected behavioral HIV prevention interventions

\begin{tabular}{|c|c|c|c|c|}
\hline Study & Sample & Intervention format & Intervention duration & Partner reduction outcomes \\
\hline Wenger et al. [14] & $\begin{array}{l}\text { STD clinic patients, } \\
\text { USA }\end{array}$ & $\begin{array}{l}\text { HIV information }+ \text { HIV testing } \\
\text { HIV information }\end{array}$ & $\begin{array}{l}15 \text { min video } \\
10 \text { min counseling }\end{array}$ & $\begin{array}{l}\text { Both groups decreased numbers of partners } \\
\text { from baseline to follow-up; HIV information } \\
1.7-1.3 \text {; Information }+ \text { testing } 1.9-1.4 \text {, with } \\
\text { no difference between conditions }\end{array}$ \\
\hline Jemmott et al. [15] & $\begin{array}{l}\text { African-American } \\
\text { adolescent males, } \\
\text { USA }\end{array}$ & $\begin{array}{l}\text { HIV risk reduction counseling } \\
\text { Career counseling control }\end{array}$ & $\begin{array}{l}5 \mathrm{~h} \text { single session } \\
\text { workshop }\end{array}$ & $\begin{array}{l}\text { HIV prevention intervention had fewer partners } \\
\text { at the } 6 \text { month follow-up }\end{array}$ \\
\hline Malow et al. [16] & $\begin{array}{l}\text { Substance users in } \\
\text { recovery, USA }\end{array}$ & $\begin{array}{l}\text { Psychoeducational HIV risk reduction } \\
\text { program } \\
\text { Information session control }\end{array}$ & $\begin{array}{l}6 \mathrm{~h} \text { of small group } \\
\text { sessions }\end{array}$ & $\begin{array}{l}\text { HIV risk reduction intervention reduced } \\
\text { partners with } 75 \% \text { reporting multiple partners } \\
\text { at baseline and } 47 \% \text { at } 6 \text { month follow-up }\end{array}$ \\
\hline $\begin{array}{l}\text { St. Lawrence et al. } \\
\text { [17] }\end{array}$ & $\begin{array}{l}\text { African-American } \\
\text { adolescents, USA }\end{array}$ & $\begin{array}{l}\text { Behavioral skills training } \\
\text { Educational program control }\end{array}$ & $\begin{array}{l}8 \text { weekly group } \\
\text { sessions }\end{array}$ & $\begin{array}{l}\text { Skills training intervention reduced partners } \\
0.7-0.3 \text { over } 12 \text { months follow-up compared } \\
\text { to } 0.8-0.7 \text { for the Education Program }\end{array}$ \\
\hline Choi [18] & $\begin{array}{l}\text { Self identified Asian } \\
\text { Pacific Islander Gay } \\
\text { men, USA }\end{array}$ & $\begin{array}{l}\text { Behavioral skills training workshop } \\
\text { Waitlist control }\end{array}$ & $\begin{array}{l}3 \text { h single session } \\
\text { workshop } \\
\text { Wait-list control group }\end{array}$ & $\begin{array}{l}\text { Behavioral skills workshop had fewer partners } \\
\text { (3.9) at the } 3 \text { month follow-up compared to } \\
\text { waitlist (6.4) }\end{array}$ \\
\hline Kelly et al. [19] & $\begin{array}{l}\text { Psychiatric patients, } \\
\text { USA }\end{array}$ & $\begin{array}{l}\text { Cognitive behavioral skills } \\
\text { training }+ \text { advocacy training } \\
\text { Cognitive behavioral skills training } \\
\text { AIDS education control }\end{array}$ & $\begin{array}{l}\text { Seven } 90 \text { min small } \\
\text { group sessions for } \\
\text { skills interventions } \\
60 \text { min education }\end{array}$ & $\begin{array}{l}\text { Cognitive behavioral skill training }+ \text { advocacy } \\
\text { training reduced partners over } 3 \text { months from } \\
1.7 \text { to } 0.9 \text {, but cognitive behavioral skills } \\
\text { alone did not, from } 0.9 \text { to } 0.9\end{array}$ \\
\hline Kamb et al. [20] & $\begin{array}{l}\text { STI clinic patients } \\
\text { receiving HIV testing }\end{array}$ & $\begin{array}{l}\text { Standard single session risk reduction } \\
\text { counseling } \\
\text { Standard counseling plus ongoing group } \\
\text { intervention }\end{array}$ & $\begin{array}{l}20 \text { min post HIV } \\
\text { test }+ \text { three } 60 \mathrm{~min} \\
\text { groups }\end{array}$ & $\begin{array}{l}\text { Brief standard session reduced number of new } \\
\text { and casual partners over the other conditions }\end{array}$ \\
\hline & & Didactic health messages & $5 \mathrm{~min}$ & \\
\hline $\begin{array}{l}\text { St. Lawrence et al. } \\
\text { [21] }\end{array}$ & $\begin{array}{l}\text { Drug-dependent } \\
\text { adolescents, USA }\end{array}$ & $\begin{array}{l}\text { Information }+ \text { skills based safer } \\
\text { sex }+ \text { risk sensitization } \\
\text { Health information }+ \text { safer sex skills- } \\
\quad \text { based training } \\
\text { Health information control }\end{array}$ & $1290 \mathrm{~min}$ sessions & $\begin{array}{l}\text { Baseline to } 12 \text { month follow-up, both skills- } \\
\text { based conditions showed greater decrease in } \\
\text { number of partners; information }+ \text { skills, } \\
\text { reduced from } 5.1 \text { to } 1.6 \text { partners, the } \\
\text { information }+ \text { skills }+ \text { sensitization from } \\
4.8 \text { to } 1.6\end{array}$ \\
\hline $\begin{array}{l}\text { Rotheram-Borus } \\
\text { et al. [22] }\end{array}$ & $\begin{array}{l}\text { Runaway adolescents } \\
\text { from four shelters, } \\
\text { USA }\end{array}$ & $\begin{array}{l}\text { Street smart intervention: HIV } \\
\text { knowledge, coping skills, barriers to } \\
\text { safe sex, emotional regulation, risk } \\
\text { assess } \\
\text { Care as usual control group }\end{array}$ & $\begin{array}{l}\text { Nine small group } \\
\text { sessions }\end{array}$ & $\begin{array}{l}\text { Average number of partners lower for } \\
\text { intervention condition at } 24 \text { month follow-up } \\
\text { among females but not for males }\end{array}$ \\
\hline Shain et al. [23] & $\begin{array}{l}\text { Women STI clinic } \\
\text { patients, USA }\end{array}$ & $\begin{array}{l}\text { HIV prevention small group sessions } \\
\text { HIV prevention }+ \text { monthly support } \\
\text { groups } \\
\text { Control condition }\end{array}$ & $\begin{array}{l}\text { HIV prevention } 3 \text { - } \\
\text { weekly } 3 \text {-h group } \\
\text { sessions }\end{array}$ & $\begin{array}{l}\text { HIV Prevention intervention reduced new STI } \\
\text { infections and reduced multiple sex partners. } \\
\text { Reductions in multiple sex partners explained } \\
\text { protection against STI }\end{array}$ \\
\hline Carey et al. [24] & $\begin{array}{l}\text { Psychiatric patients, } \\
\text { USA }\end{array}$ & $\begin{array}{l}\text { HIV risk reduction } \\
\text { Substance abuse reduction } \\
\text { Standard of care control }\end{array}$ & $\begin{array}{l}\text { Ten small group } \\
\text { sessions }\end{array}$ & $\begin{array}{l}\text { Pre-intervention to } 6 \text { month follow-up: } \\
\text { HIV } 1.25-0.97 \\
\text { SUR } 1.41-0.95 \\
\text { CTR } 1.24-1.07 \\
\text { HIV risk reduction reduced number of partners } \\
\text { from } 1.2 \text { to } 0.9 \text {, and substance use reduction } \\
\text { interventions reduced number of partners } \\
\text { from } 1.4 \text { to } 0.9 \text {; both reductions were greater } \\
\text { than standard of care control, from } 1.2 \text { to } 1.0\end{array}$ \\
\hline Jemmott et al. [25] & $\begin{array}{l}\text { Latin/African } \\
\text { American adolescent } \\
\text { females, USA }\end{array}$ & $\begin{array}{l}\text { Skills based counseling } \\
\text { Information based counseling } \\
\text { Health promotion counseling control }\end{array}$ & $\begin{array}{l}4.5 \mathrm{~h} \text { single session } \\
\text { workshop }\end{array}$ & $\begin{array}{l}\text { Skills based intervention had greater decrease } \\
\text { in partners from baseline to } 12 \text { month follow- } \\
\text { up (1.04-0.93) compared to information } \\
\text { based and health promotion conditions }\end{array}$ \\
\hline $\begin{array}{l}\text { Kalichman et al. } \\
\text { [26] }\end{array}$ & $\begin{array}{l}\text { STI clinic patients, } \\
\text { South Africa }\end{array}$ & $\begin{array}{l}\text { Motivation/skills HIV and alcohol use } \\
\text { risk reduction counseling } \\
\text { HIV information control }\end{array}$ & $\begin{array}{l}60 \text { min single } \\
\text { counseling session } \\
20 \text { min single } \\
\text { counseling session }\end{array}$ & $\begin{array}{l}\text { Motivational/skills condition reduced number } \\
\text { of partners from } 2.5 \text { to } 1.2 \text {, with no difference } \\
\text { from the control condition }\end{array}$ \\
\hline
\end{tabular}


Table 1 continued

\begin{tabular}{|c|c|c|c|c|}
\hline Study & Sample & Intervention format & Intervention duration & Partner reduction outcomes \\
\hline $\begin{array}{l}\text { Kalichman et al. } \\
\text { [27] }\end{array}$ & $\begin{array}{l}\text { Men who use alcohol } \\
\text { recruited from } \\
\text { community venues, } \\
\text { South Africa }\end{array}$ & $\begin{array}{l}\text { Alcohol-sex risk reduction skills } \\
\text { workshop } \\
\text { Alcohol risk education control }\end{array}$ & $\begin{array}{l}\text { Single } 3 \mathrm{~h} \text { session } \\
\text { Single } 1 \mathrm{~h} \text { session }\end{array}$ & $\begin{array}{l}\text { Reductions in partners occurred in the skills } \\
\text { intervention, but moderated by alcohol use; } \\
\text { lighter drinkers reduced having } 2+\text { partners } \\
\text { from } 12 \% \text { at baseline to } 6 \% \text { at } 3 \text {-month and } \\
8 \% \text { at } 6 \text {-month follow-up }\end{array}$ \\
\hline Carey et al. [28] & $\begin{array}{l}\text { STD clinic patients, } \\
\text { USA }\end{array}$ & $\begin{array}{l}\text { Brief motivational counseling or brief } \\
\text { educational session } \\
\text { Intensive information groups } \\
\text { Intensive motivational and skills groups }\end{array}$ & $\begin{array}{l}15 \mathrm{~min} \\
4 \mathrm{~h} \\
4 \mathrm{~h}\end{array}$ & $\begin{array}{l}\text { Number of partners reduced from } 2.7 \text { to } 1.9 \\
\text { over } 12 \text { months with no differences between } \\
\text { experimental intervention conditions }\end{array}$ \\
\hline
\end{tabular}

that report decreased numbers of sex partners over time. All of these studies found evidence for reductions in numbers of sex partners, with eleven trials demonstrating an experimental intervention that reduced numbers of partners to a significantly greater degree than a control condition. The interventions varied in their content and duration, with some lasting several hours and conducted over multiple sessions and others having only one brief session. All of the interventions included a heavy dose of interactive training for communication and preventive behavioral skills. The interventions were tested in various settings and with a wide range of populations including men who have sex with men, women, substance users, adolescents, and patients attending sexually transmitted infection clinics. The magnitude of partner reduction varied, with some studies showing more than a three-fold reduction in numbers of sex partners over time.

Examining the outcomes reported in these trials suggests that reducing numbers of sex partners may not be any more difficult to achieve than changing other sexual behaviors, such as increasing condom use. However, reductions in sexually transmitted infections (STI) has not been directly linked to partner reductions relative to other changes in behavior. Research is needed to better understand motivations for maintaining multiple sex partners and how the meaning of multiple partners differs by gender, sexual orientation, and culture. The importance of multiple sex partners in facilitating the spread of HIV is indisputable. The importance of acute HIV infection in HIV transmission also applies to multiple partners even if non-overlapping and should therefore remain a focus in HIV prevention. Interventions that have shown promise in reducing numbers of sex partners are available and should be implemented in places with high-HIV prevalence and high-rates of multiple partners, concurrent or not. Given that the role of sexual concurrency in HIV epidemics is not known, limited HIV prevention resources should be concentrated on known risks and evidence-based interventions.

Acknowledgments Preparation of this Editorial was supported the National Institute of Alcohol Abuse and Alcoholism Grant RC1AA018983.

\section{References}

1. Mah TL, Halperin DT. Concurrent sexual partnerships and the HIV epidemics in Africa: evidence to move forward. AIDS Behav. 2010;14(1):11-6 (dicussion 34-7).

2. Bohl DD, Raymond HF, Arnold M, McFarland W. Concurrent sexual partnerships and racial disparities in HIV infection among men who have sex with men. Sex Transm Infect. 2009;85(5): $367-9$.

3. Choi KH, Hudes ES, Steward WT. Social discrimination, concurrent sexual partnerships, and HIV risk among men who have sex with men in Shanghai, China. AIDS Behav. 2008;12(4 Suppl):S71-7.

4. Steward WT, Remien RH, Higgins JA, Dubrow R, Pinkerton SD, Sikkema KJ, et al. Behavior change following diagnosis with acute/early HIV infection-a move to serosorting with other HIV-infected individuals. The NIMH Multisite Acute HIV Infection Study: III. AIDS Behav. 2009.

5. Morris M. Barking up the wrong evidence tree. Comment on Lurie \& Rosenthal, "Concurrent partnerships as a driver of the HIV epidemic in sub-Saharan Africa? The evidence is limited". AIDS Behav. 2010;14(1):31-3 (discussion 4-7).

6. Epstein $\mathrm{H}$. The mathematics of concurrent partnerships and HIV: a commentary on Lurie and Rosenthal, 2009. AIDS Behav. 2010;14(1):29-30 (discussion 4-7).

7. Lurie MN, Rosenthal S. Concurrent partnerships as a driver of the HIV epidemic in sub-Saharan Africa? The evidence is limited. AIDS Behav. 2010;14(1):17-24 (discussion 5-8).

8. Lurie MN, Rosenthal S. The concurrency hypothesis in subSaharan Africa: convincing empirical evidence is still lacking. Response to Mah and Halperin, Epstein, and Morris. AIDS Behav. 2010;14(1):34.

9. Lurie M, Rosenthal S, Williams B. Concurrency driving the African HIV epidemics: where is the evidence? Lancet. 2009; 374(9699):1420 (author reply 1420-1).

10. Reniers G, Watkins S. Polygyny and the spread of HIV in subSaharan Africa: a case of benign concurrency. AIDS. 2010;24(2):299-307.

11. Epstein H, Swidler A, Gray R, Reniers G, Parker W, Parkhurst J, et al. Measuring concurrent partnerships. Lancet. 2010;375 (9729):1869-70.

12. Slutkin G, Okware S, Naamara W, Sutherland D, Flanagan D, Carael M, et al. How Uganda reversed its HIV epidemic. AIDS Behav. 2006;10(4):351-60.

13. Parkhurst J. Evidence, politics, and Uganda's HIV sucess: moving forward ABC and HIV prevention. J Int Dev. 2010.

14. Wenger NS, Linn LS, Epstein M, Shapiro MF. Reduction of highrisk sexual behavior among heterosexuals undergoing HIV antibody testing: a randomized clinical trial. Am J Public Health. 1991;81(12):1580-5.

15. Jemmott JB III, Jemmott LS, Fong GT. Reductions in HIV riskassociated sexual behaviors among black male adolescents: 
effects of an AIDS prevention intervention. Am J Public Health. 1992;82(3):372-7.

16. Malow RM, West JA, Corrigan SA, Pena JM, Cunningham SC. Outcome of psychoeducation for HIV risk reduction. AIDS Educ Prev. 1994;6(2):113-25.

17. St Lawrence JS, Jefferson KW, Alleyne E, Brasfield TL. Comparison of education versus behavioral skills training interventions in lowering sexual HIV-risk behavior of substancedependent adolescents. J Consult Clin Psychol. 1995;63(1): 154-7.

18. Choi KH, Lew S, Vittinghoff E, Catania JA, Barrett DC, Coates TJ. The efficacy of brief group counseling in HIV risk reduction among homosexual Asian and Pacific Islander men. AIDS. 1996;10(1):81-7.

19. Kelly JA, McAuliffe TL, Sikkema KJ, Murphy DA, Somlai AM, Mulry $\mathrm{G}$, et al. Reduction in risk behavior among adults with severe mental illness who learned to advocate for HIV prevention. Psychiatr Serv. 1997;48(10):1283-8.

20. Kamb ML, Fishbein M, Douglas JM Jr, Rhodes F, Rogers J, Bolan G, et al. Efficacy of risk-reduction counseling to prevent human immunodeficiency virus and sexually transmitted diseases: a randomized controlled trial. Project RESPECT Study Group. JAMA. 1998;280(13):1161-7.

21. St Lawrence JS, Crosby RA, Brasfield TL, O'Bannon RE III. Reducing STD and HIV risk behavior of substance-dependent adolescents: a randomized controlled trial. J Consult Clin Psychol. 2002;70(4):1010-21.

22. Rotheram-Borus MJ, Lee M, Leonard N, Lin YY, Franzke L, Turner E, et al. Four-year behavioral outcomes of an intervention for parents living with HIV and their adolescent children. AIDS. 2003;17(8):1217-25.

23. Shain RN, Piper JM, Holden AE, Champion JD, Perdue ST, Korte JE, et al. Prevention of gonorrhea and Chlamydia through behavioral intervention: results of a two-year controlled randomized trial in minority women. Sex Transm Dis. 2004; 31(7):401-8.

24. Carey MP, Carey KB, Maisto SA, Gordon CM, Schroder KE, Vanable PA. Reducing HIV-risk behavior among adults receiving outpatient psychiatric treatment: results from a randomized controlled trial. J Consult Clin Psychol. 2004;72(2):252-68.

25. Jemmott JB III, Jemmott LS, Braverman PK, Fong GT. HIV/STD risk reduction interventions for African American and Latino adolescent girls at an adolescent medicine clinic: a randomized controlled trial. Arch Pediatr Adolesc Med. 2005;159(5):440-9.

26. Kalichman SC, Simbayi LC, Vermaak R, Cain D, Jooste S, Peltzer K. HIV/AIDS risk reduction counseling for alcohol using sexually transmitted infections clinic patients in Cape Town, South Africa. J Acquir Immune Defic Syndr. 2007;44(5):594600.

27. Kalichman SC, Simbayi LC, Vermaak R, et al. Randomized trial of a community-based alcohol-related HIV risk reduction intervention for men and women in CapeTown South Africa. Ann Behav Med. 2008;36:270-9.

28. Carey MP, Senn TE, Vanable PA, Coury-Doniger P, Urban MA. Brief and intensive behavioral interventions to promote sexual risk reduction among STD clinic patients: results from a randomized controlled trial. AIDS Behav. 2009. 